\title{
Anthropogenic and natural disturbance effects on a macrobenthic estuarine community over a 10-year period
}

\author{
M. Dolbeth ${ }^{\text {a,* }}$, P.G. Cardoso ${ }^{\text {a }}$, S.M. Ferreira ${ }^{\text {a }}$, T. Verdelhos ${ }^{\text {a }}$, D. Raffaelli ${ }^{\text {b }}$, M.A. Pardal ${ }^{\text {a }}$ \\ ${ }^{a}$ Institute of Marine Research (IMAR), clo Department of Zoology, University of Coimbra, 3004-517 Coimbra, Portugal \\ ${ }^{\mathrm{b}}$ Environment Department, University of York, Heslington, York YO10 5DD, UK
}

\begin{abstract}
For some decades, the Mondego estuary has been under severe ecological stress, mainly caused by eutrophication. The most visible effect was the occurrence of macroalgal blooms and the concomitant decrease of the area occupied by Zostera noltii beds. Since the end of 1998, mitigation measures were implemented in the estuary to promote the recovery of the seagrass beds and the entire surrounding environment. The present study offers a unique opportunity to evaluate the impact of disturbance and the success of the initial recovery process (before and after implementation of the management measures), over a 10-year period, having secondary production as the descriptor. Before the implementation of the mitigation measures, in parallel with the decrease of the Z. noltii beds, species richness, mean biomass and production also decreased, lowering the carrying capacity of the whole Mondego's south arm. Yet, after the introduction of management measures, the seagrass bed seemed to recover. Consequently, the biomass and production also increased substantially, for the whole intertidal area. Nevertheless, even after the mitigation measures implementation, natural-induced stressors, such as strong flood events induced a drastic reduction of annual production, not seen before the implementation of those measures. This shows that the resilience of the populations may have been lowered by a prior disturbance history (eutrophication) and consequent interactions of multiple stressors.
\end{abstract}

(C) 2006 Elsevier Ltd. All rights reserved.

Keywords: Macrobenthic production; Disturbance; Mitigation measures; Recovery

\section{Introduction}

Estuaries are among the most productive natural ecosystems (Kennish, 2002; Dolbeth et al., 2003; Paerl, 2006). Their importance is recognised worldwide, for providing essential ecological functions (decomposition, nutrient cycling and flux regulation of water, particles and pollutants) and services, such as habitat, protection, food for migratory and resident species, shoreline protection, fisheries resources, navigation routes and harbours, and recreational purposes (Kennish, 2002; Paerl, 2006). As transitional areas between land and sea, most estuaries and coastal lagoons receive large amounts of nutrients

\footnotetext{
* Corresponding author. Tel.: +351239 836386; fax: +351239823603.

E-mail address: mdolbeth@ci.uc.pt (M. Dolbeth).
}

and pollutants derived from urban, agricultural and industrial effluents (Lillebø et al., 2005; Paerl, 2006). Due to the shallow depth and relatively weak exchange with the open sea, these systems are particularly vulnerable to eutrophication, recognised as a major problem worldwide (Kennish, 2002; Marques et al., 2003; Pardal et al., 2004; Lillebø et al., 2005; Munkes, 2005; Powers et al., 2005). In addition, global warming and sea-level rise will have important consequences for aquatic ecosystems (Short and Neckles, 1999; Simas et al., 2001; Lawrence and Soame, 2004; Beukema and Dekker, 2005). A major challenge for ecologists is the understanding of the ecosystem functioning and dynamics in the face of natural, anthropogenically-induced and extreme climate variability. One approach to this is through an analysis of the different components of the system contributing to production, widely used to assess the ecological integrity of ecosystems, 
including anthropogenic effects or climate change effects (Brey, 2001; Dolbeth et al., 2003; Cusson and Bourget, 2005; Polte et al., 2005). Here, changes are described in the macrobenthic secondary production of the Mondego estuary, Portugal, over a 10-year period, during which the system has undergone significant eutrophication and more recently has experienced extreme weather-related events. The impacts of these stressors on the population dynamics of key species have been described elsewhere (Pardal et al., 2000; Cardoso et al., 2004a, 2005; Ferreira et al., 2004; Verdelhos et al., 2005). At the end of 1998, a management plan was implemented to restore the estuary, which included measures to improve water transparency, decrease nutrient loading and the physical protection of the seagrass bed (Lillebø et al., 2005; Martins et al., 2005). In the present paper, we assess the impact of these stressors and the effectiveness of the mitigation programme at the ecosystem-level through an exploration of the changes in macrobenthic secondary production.

\section{Materials and methods}

\subsection{Study area}

The Mondego estuary (Portugal) is located in a warm temperate region, on the Atlantic coast of Portugal $\left(40^{\circ} 08^{\prime} \mathrm{N}, 8^{\circ} 50^{\prime} \mathrm{S}\right)$. It is a small estuary of $3.4 \mathrm{~km}^{2}$, comprising two arms, north and south, separated by an island. The north arm is deeper ( $4-8 \mathrm{~m}$ during high tide, tidal range 1-3 m), highly hydrodynamic and provides the main navigation channel and the location of the Figueira da Foz harbour. The south arm is shallower (2-4 m during high tide, tidal range $1-3 \mathrm{~m}$ ) and is characterized by large areas of exposed intertidal flats during low tide. Anthropogenic activities in the estuary led to an ongoing process of eutrophication since the end of the 1980s, mainly in the south arm. The downstream areas of the south arm still remain relatively unchanged, with Spartina maritima marshes and a Zostera noltii meadow, but in the inner parts the seagrass community has completely disappeared and blooms of the opportunistic macroalgae Ulva spp. were common. The macroalgae Ulva spp. blooms consisted in the rapid growth and accumulation of biomass of these species, due to the combination of the nutrient surplus with low hydrodynamics and high salinity (Martins et al., 2005).

Until the end of 1998 this sub-system was almost silted up in the upstream areas. Water circulation was therefore mainly dependent on tides and on the freshwater input from the Pranto river (Fig. 1), artificially controlled by a sluice, according to rice field irrigation needs in the lower Mondego valley (Pardal et al., 2004; Cardoso et al., 2005; Lillebø et al., 2005).

This sub-system is recently and gradually recovering from the effects of eutrophication after the implementation of mitigation measures in 1998 which improved water transparency and decreased nutrient loading (Cardoso

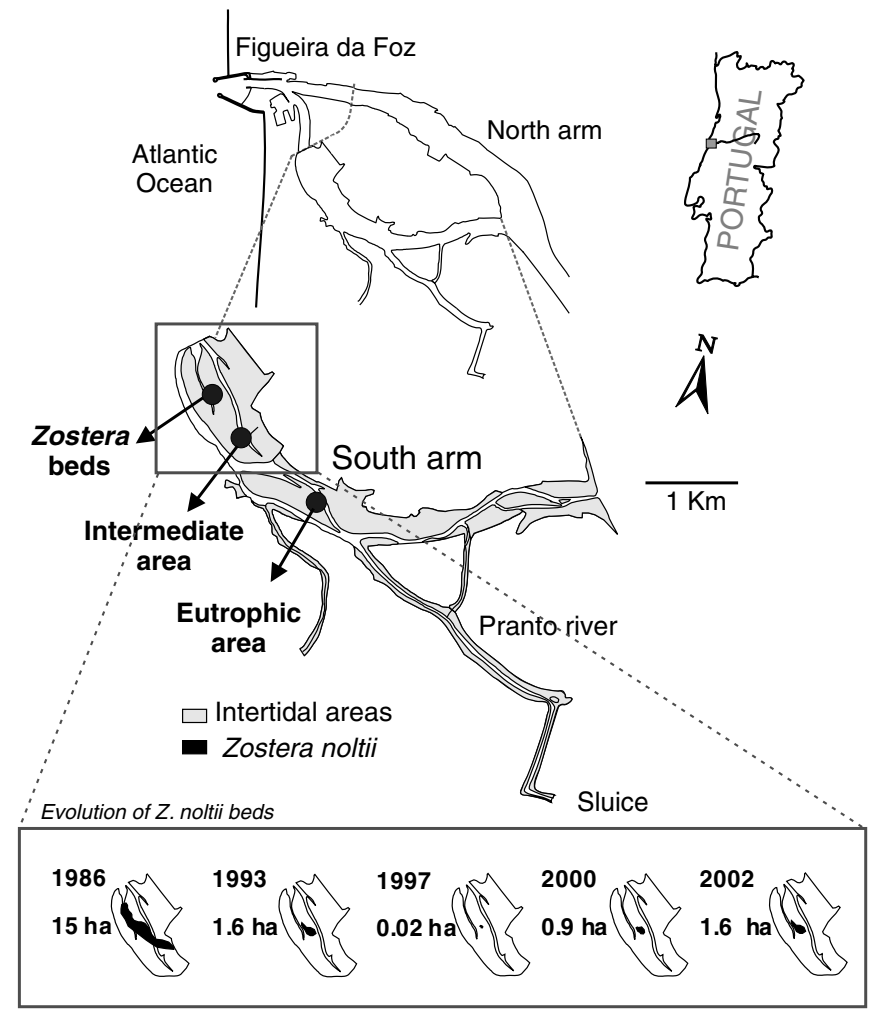

Fig. 1. Location of the Mondego estuary showing sampling stations. Expanded area maps show evolution of the $Z$. noltii bed's area and cover, since 1986.

et al., 2005; Lillebø et al., 2005). These included: (1) the re-establishment of the south arm riverhead connection, improving freshwater circulation; (2) nutrient loading reduction, essentially ammonia (Lillebø et al., 2005); (3) seagrass bed protection from human disturbance; and (4) public education of the ecological importance of intertidal vegetation for health and related socio-economic activities of the estuary.

In these last years several differences in the climate of Portugal have been recorded when compared to the general climate patterns for period 1931-1990. There was a clear increase of mean air temperature (from 1931 to 2005: $+0.15^{\circ} \mathrm{C}$ per decade) and a high variability in precipitation (INAG - Portuguese Water Institute, http://snirh.inag.pt/ and IM - Portuguese Weather Institute, http://web.meteo. $\mathrm{pt} / \mathrm{pt} / \mathrm{clima} / \mathrm{clima}$.jsp). For instance, during the winter of 2000/01 precipitation reached unprecedented high values, especially for the central Portugal (2000/01: $1802.1 \mathrm{~mm}$ against a mean annual value for 1940 to $1997: 1030.6 \mathrm{~mm}$ ), causing a large flood.

\subsection{Sampling and biological material processing}

Samples were taken during low tide in three areas representing different environments along the eutrophication gradient: (1) the seagrass bed, characterized by muddy sediments covered with $Z$. noltii, higher organic matter 
content (mean $6.2 \% \pm 1.76$ ), and higher water-flow velocity (1.2-1.4 $\left.\mathrm{m} \mathrm{s}^{-1}\right)$ compared to the other 2 areas; (2) an intermediate area, characterized by muddy sediments and some roots of $Z$. noltii, with physical-chemical conditions similar to those of the previous area; (3) a eutrophic area, characterized by sandy sediments, which has not supported rooted macrophytes for more than 15 years, lower organic matter content (mean $3.0 \% \pm 1.14$ ), lower water flows $(0.8$ $1.2 \mathrm{~m} \mathrm{~s}^{-1}$ ) and which has been regularly covered seasonally by green macroalgae (Fig. 1). The sampling technique described by Dexter (1983) for intertidal sandy beaches was adapted for the Mondego estuary intertidal soft sediments. So, ten (during the first 18 months) to six sediment cores $\left(141 \mathrm{~cm}^{2}\right.$ core sectional area) were randomly taken to a depth of $20 \mathrm{~cm}$, by using a manual corer. Samples were collected in the morning, during low tide, fortnightly for the first 18 months, monthly thereafter. For the results section, data were merged to present only the seasonal variations. Each sample was sieved through a $500 \mu \mathrm{m}$ mesh using estuarine water and then preserved in $4 \%$ buffered formalin. Organisms were identified to the species level, counted and measured. Plant material was sorted and separated into green algae and $Z$. noltii. For both faunal and plant material the ash-free dry weight (AFDW) was assessed, after combustion for $8 \mathrm{~h}$ at $450{ }^{\circ} \mathrm{C}$ (shells of molluscs included).

\subsection{Secondary production}

For Hydrobia ulvae (Gastropoda), Cyathura carinata (Isopoda), Ampithoe valida, and Melita palmata (Amphipoda), secondary production was estimated by the increment summation method, after definition of cohorts through size-frequency distribution analysis of successive sampling dates and using ANAMOD software (after Pardal et al., 2000; Ferreira et al., 2004; Cardoso et al., 2005; Verdelhos et al., 2005; Dolbeth et al., 2005), according to:

$P_{c n}=\sum_{t=0}^{T-1}\left(\frac{N_{t}+N_{t+1}}{2}\right) \times\left(\bar{w}_{t+1}-\bar{w}_{t}\right)$

where $P_{c n}$ is the growth production of cohort $n ; N$ is the density (ind $\mathrm{m}^{-2}$ ); $\quad \bar{w}$ is the mean individual weight $\left(\mathrm{g} \mathrm{WW} \mathrm{m}^{-2}\right.$ ); and $t$ and $t+1$, consecutive sampling dates. Population production estimates correspond to the sum of $P_{c n}$ (each cohort production):

$P=\sum_{n=1}^{N} P_{c n}$

The mean annual biomass $(\bar{B})$ was estimated according to:

$\bar{B}=\left(\frac{1}{T}\right) \times \sum_{n=1}^{N}\left(\bar{B}_{c n} t\right)$ where $T$ is the period of study (yearly cycles, 365 days); $N$ is the number of successive cohorts in the study period; $\bar{B}_{c n}$ is the mean biomass of cohort $n ; t$ is the duration of the cohort $n$.

Brey (2001) method version 4-04 (worksheet provided in Brey 2001, www.awi-bremerhaven.de/Benthic/Ecosystem/ FoodWeb/Handbook/main.htm) was used as an alternative empirical method for secondary production estimation (after Cusson and Bourget, 2005; Dolbeth et al., 2005) for other representative species - Carcinus maenas, Crangon crangon (Decapoda), Capitella capitata, Hediste diversicolor, Heteromastus filiformis (Polychaeta), Cerastoderma edule, Scrobicularia plana (Bivalvia), Haminoea hydatis and Littorina littorea (Gastropoda). The weight-to-energy ratios needed for the application of the empirical method are also provided in Brey (2001). For the species with lower densities and biomasses, production was estimated by summing the increases in biomasses from one sampling date to the other, using the cohort increment summation equation (Eq. (1)), but without following the cohorts.

Mean biomass and $P / \bar{B}$ ratios (annual production divided by the annual mean biomass) were also computed for the main species. The $P / \bar{B}$ ratio is the turnover rate of a species' biomass, meaning the amount of time it takes to replace the biomass of its population (McLusky, 1989; Cusson and Bourget, 2005). It is closely related to the species' life span and affected by life history characteristics and potentially also by environmental factors (in a indirect way), being a clear indication of the ecological performance of a population (McLusky, 1989; Cusson and Bourget, 2005). Long lived species will have lower $P / \bar{B}$ than short lived species (McLusky, 1989).

Each species production was then cumulated into community production. Biomass and production within the community is represented essentially by detritivores (Dolbeth et al., 2003; Cardoso et al., 2004a).

\subsection{Multivariate analysis}

The production distribution within the macrobenthic community at different sites in different years was investigated using multivariate techniques provided by the PRIMER software (version 5.2.6, PRIMER-E Ltd.), in order to investigate if there were spatial and temporal differences in the production of each area, before and after the mitigation periods. Similarity relationships of the production results were determined by Bray-Curtis coefficient, after square-root-transformation of the raw data. Square-roottransformation of the data was used in order to scale down the scores of the very productive species (Clarke and Warwick, 2001). Non-metric MDS analysis was performed afterwards, from which similar groups were defined. One way ANOSIM tests (Clarke and Warwick, 2001) were used to test for differences between groups. For each group, a Similarity Percentages-species contributions (SIMPER) was used to determine which species' production contributed most to the differences among the groups. 


\section{Results}

\subsection{Climate - precipitation}

In the Mondego estuary there was a clear seasonal pattern of rainfall over the 10-year period, with the highest precipitation values in the winter (Fig. 2a). Yet, taking into consideration the mean precipitation regime for central Portugal during the period of 1940-1997 (winter: $418 \mathrm{~mm}$, spring: $265 \mathrm{~mm}$, summer: $62 \mathrm{~mm}$, autumn: $285 \mathrm{~mm}$, INAG - http://snirh.inag.pt) some above-mean precipitation was evident (Fig. 2a). The hydrological years of 1993/94 (autumn: $593 \mathrm{~mm}$ ) and 1995/96 (winter: $670 \mathrm{~mm}$ ) were atypical, suffering floods, and 2000/01 was even more atypical, with severe flooding occurring (winter: $767 \mathrm{~mm}$ ) (INAG - http://snirh.inag.pt).

The seasonal pattern of rainfall and the flooding are reflected in the seasonal and inter-annual variation of salinity in the south arm. During periods of intense rainfall, salinity declined dramatically (Fig. 2a), occasionally reaching $<5$ (Feb 96, Jan 97 and Jan 01). Also, during these times of high rainfall there was an extensive opening of the Pranto River sluice, further contributing to the salinity decline (Lillebø et al., 2005).

\subsection{Seagrass and macroalgal biomass}

There was a clear seasonal pattern of the seagrass biomass over the study period with higher biomass in spring/summer and lower in autumn/winter. However, seagrass biomass showed a significant decline over the pre-mitigation period, from 1993 to 1997 (Fig. 2b, $R^{2}=$ 0.89 ). After the mitigation measures were introduced in 1998 , there seems to be a gradual recovery of the seagrass bed (Fig. 2b, $R^{2}=0.56$ ). Significant differences were observed when comparing the pre-mitigation with the post-mitigation period (Student's $t$-test, $t_{[16,17]}=2.88$, $p<0.05$ ).

In the intermediate area, the biomass of green algae showed a characteristic seasonal pattern until 1997, with lower values during winter, following the decrease of salinity (Fig. 2a), and increasing in spring and summer (Fig. 2c). In the eutrophic area, there was a spring bloom in 1993 (maximum biomass of $415 \mathrm{~g} \mathrm{AFDW} \mathrm{m}^{-2} / 508 \mathrm{~g} \mathrm{DW} \mathrm{m}^{-2}$ in April 1993), followed by a crash in early summer (Fig. 2d). In 1995, algal biomass again reached high values, but not enough to be considered a spring bloom (maximum biomass of $111 \mathrm{~g} \mathrm{AFDW} \mathrm{m}^{-2} / 142 \mathrm{~g} \mathrm{DW} \mathrm{m}^{-2}$ in April 1995) (Fig. 2d). Several studies on macroalgal blooms and mats have reported algae biomass in these periods ranging from 425 to $625 \mathrm{~g} \mathrm{DW} \mathrm{m}^{-2}$ (Pihl et al., 1996), comparable to the reported values for the Mondego estuary bloom. In both intermediate and eutrophic areas, differences were evident in algal biomass between the pre- and post-mitigation periods. Macroalgal blooms in the eutrophic area and some macroalgae in the intermediate area were present in the pre-mitigation period, particularly dur- ing dry years, but blooms were never recorded after the post-mitigation measures (Fig. $2 \mathrm{c}$ and d).

\subsection{Macrobenthic community}

\subsubsection{Species richness, abundance and biomass}

A total of 80 different taxa were recorded over the 10 -year period. In general, the number of species, mean biomass and abundance were higher in the $Z$. noltii beds compared to the other two areas (Fig. 3).

In the pre-mitigation period, there was a clear decrease in the number of species for the intermediate and eutrophic areas, which was more pronounced after the floods (Fig. 3a). In the Z. noltii beds, there was a pronounced decrease after the 1993/94 flood, followed by an increase until the end 1995 (Fig. 3a). Yet, the species number was much lower at the beginning of the post-mitigation, suggesting a considerable decrease after 1995 (Fig. 3a). With the recovery process, in the post-mitigation period, there was a tendency for the species number increase, but the values seen in 1993 were not attained again. The post-mitigation increase was interrupted in 2000/01 following major floods, continuing afterwards, a pattern seen in all three areas (Fig. 3a).

For the pre-mitigation period, in both $Z$. noltii and eutrophic areas there was a decrease in biomass between 1993 and 1994, followed by a slight increase until 1995 (more pronounced in the eutrophic area), and in the eutrophic area biomass decreased again after the summer of 1996. In the post-mitigation period, with the recovery process, mean biomass was low at the start but increased until the 2000/01 flooding and continued afterwards until the end of 2002 (Fig. 3b). For the intermediate area, biomass tended to increase throughout the study period. Mean densities showed a clear seasonal pattern in both $Z$. noltii and intermediate areas, with higher values in spring and summer throughout the study period.

In the eutrophic area mean density and biomass were high during spring 1993 and spring 1995 (Fig. 3c). Those periods matched with the periods of higher macroalgal biomass (Fig. 2d). In the following period the values appeared to maintain a relatively stability.

\subsubsection{Secondary production}

3.3.2.1. Total production. In general, higher annual production and mean biomass values were recorded in the $Z$. noltii beds than in the other two areas (Table 1), except in 1999 in the beginning of the post-mitigation period (Table 1). Both the $Z$. noltii beds and intermediate area production was greatest in 1994 and 2002. In these years, the area covered with $Z$. noltii was practically the same $(1.4 \%$ of the intertidal area, Table 1). For the eutrophic area, production was highest in 1993 (Table 1) when a macroalgal bloom occurred (Fig. 2d). Production was lowest in 1999, when $Z$. noltii cover and biomass were least (Fig. 2b), for both intermediate area and $Z$. noltii beds (Table 1). After the 


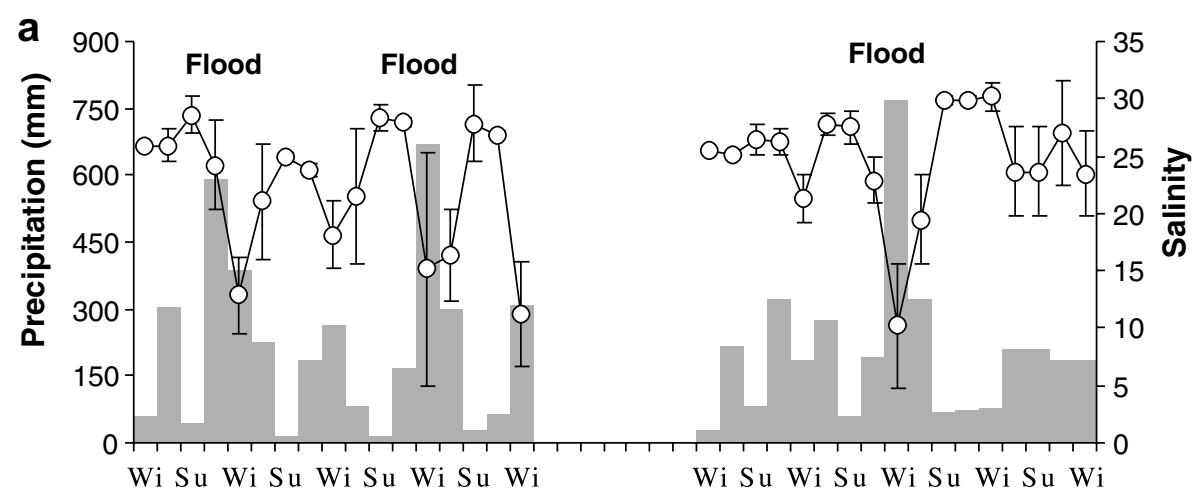

$\square$ Precipitation $\multimap-$ Salinity
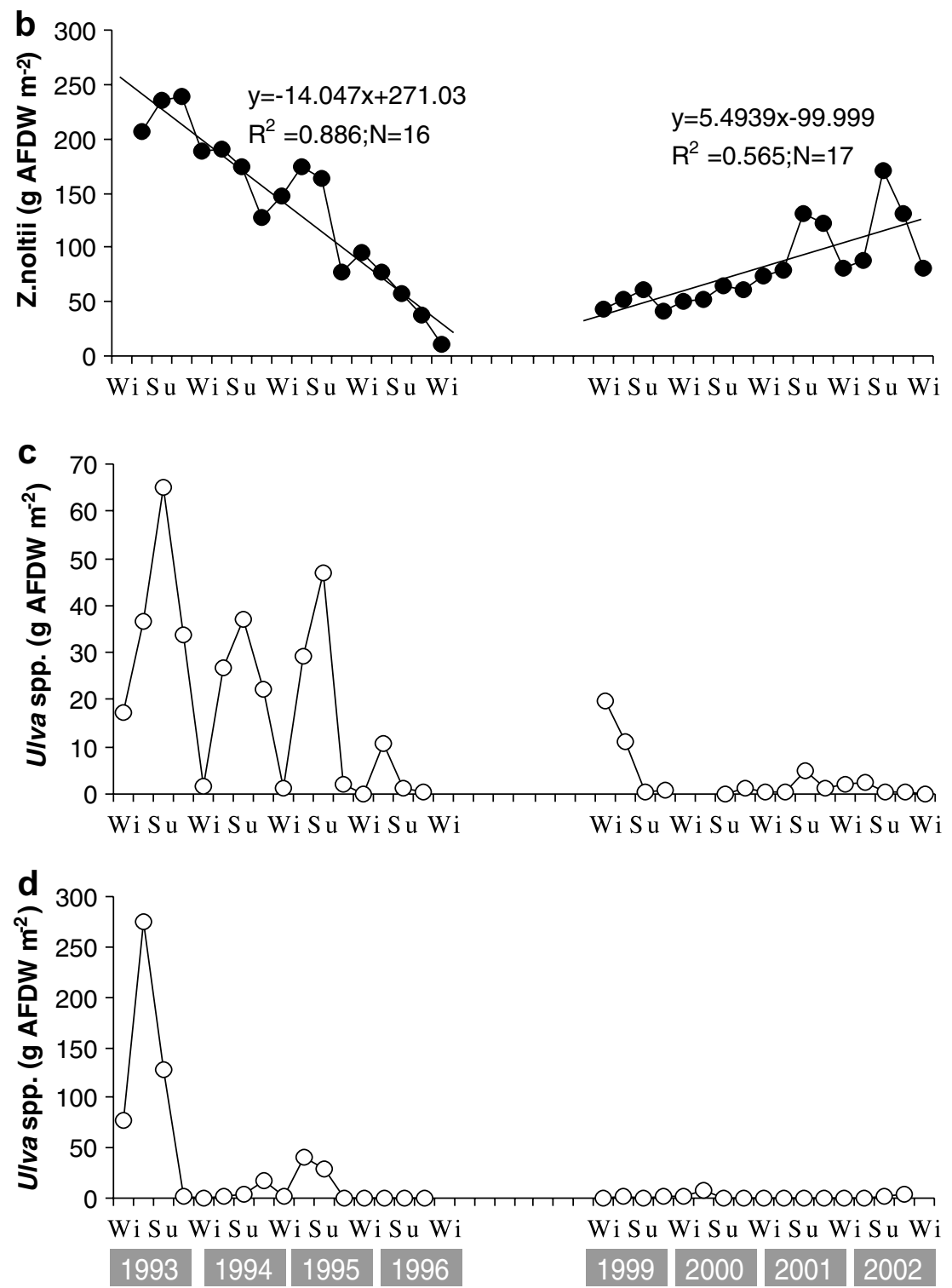

Fig. 2. Seasonal long-term variation in: (a) mean salinity and rainfall in all three areas; (b) seagrass biomass in the Z. noltii beds; (c) macroalgal biomass in the intermediate area; (d) macroalgal biomass in the eutrophic area.

mitigation measures, the production increased gradually, with a decrease in 2001, following the highest flood event.
3.3.2.2. Contrasting areas. The MDS analysis was performed only for the most contrasting environments, $Z$. noltii beds (least disturbed) and the eutrophic area (most 

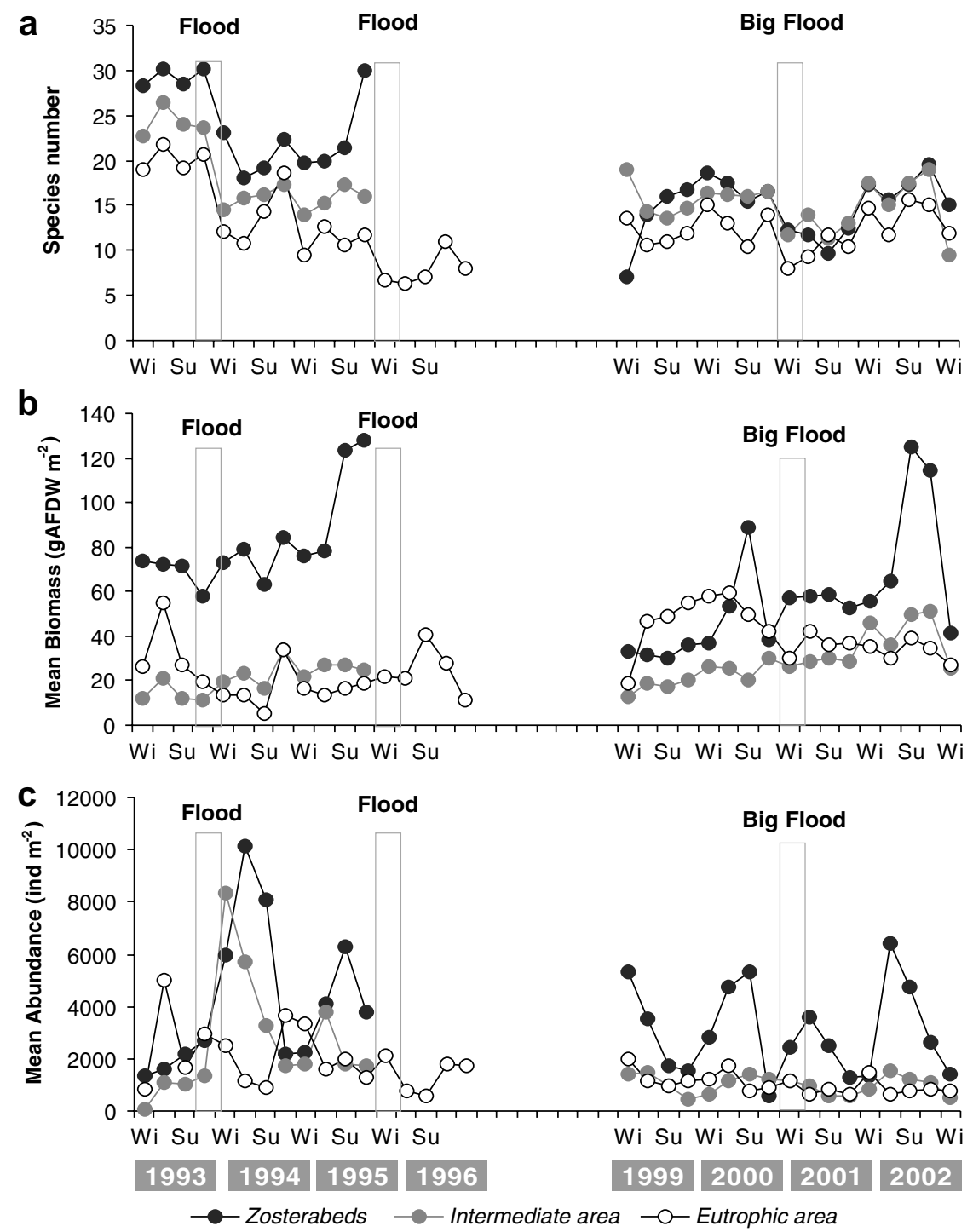

Fig. 3. Seasonal long-term variation of: (a) species richness; (b) mean biomass; and (c) mean density, for the Z. noltii beds, intermediate and eutrophic areas.

disturbed). The intermediate area is still undergoing change (Marques et al., 2003). The MDS analysis revealed that the areas are indeed distinct in terms of their production characteristics (AB versus $\mathrm{CD}$, ANOSIM test: $R=0.888$ to $p=0.001)$ and that there are also important differences pre- and post-mitigation (A versus $\mathrm{B}$ and $\mathrm{C}$ versus $\mathrm{D}$, ANOSIM test: $R=0.859$ to $p=0.001$ ) (Fig. 4, Table 2). SIMPER analysis showed that in the $Z$. noltii beds, in the pre-mitigation period, at least 9 species were necessary to explain $80 \%$ (simper cut-off) of the group similarity, yet $H$. ulvae accounted for the higher contribution. After the mitigation measures only 5 species were needed to explain $80 \%$ (simper cut-off), with $H$. ulvae, S. plana and $H$. diversicolor as major species (Table 2). In the eutrophic area only 4-5 species were necessary, before and after mitigation measures implementation, to explain between $86 \%$ and $87 \%$ of the similarity. Of these species, S. plana, C. carinata, $H$. ulvae and $H$. diversicolor were consistently identi- fied and their contribution was more evenly distributed (Table 2).

3.3.2.3. Main species. Hydrobia ulvae was the dominant species within the $Z$. noltii beds. In some of the years, the production of this species alone represented the major part of the total annual community production (e.g. 1993, 1994, 1995 and 2002, Tables 1 and 3). This species also contributed to production in the eutrophic area in the pre-mitigation period (Table 3). The $P / \bar{B}$ ratio of $H$. ulvae was much higher in the eutrophic area (between 2.7 and 4.8 ) than in the $Z$. noltii beds (between 1.3 and 3.0).

The production of $S$. plana was higher in the eutrophic area, showing a significant increase after the introduction of mitigation measures accompanied by the increase of mean annual biomass (Table 3 ). The $P / \bar{B}$ ratios for this species also decreased in this period. Like $H$. ulvae, in 2001, after the extreme flood, there was a decrease in 
Table 1

Macrobenthic community production estimates $\left(P: \mathrm{g} \mathrm{AFDW} \mathrm{m}^{-2} \mathrm{yr}^{-1}\right.$ ) and mean biomass (between brackets, $\left.\bar{B}: \mathrm{g} \mathrm{AFDW} \mathrm{m}^{-2}\right)$ for each habitat and mean estimate for the south arm intertidal area (without Spartina and Scirpus marshes) of the Mondego estuary, taking into account the area of each habitat relative to the whole intertidal area

\begin{tabular}{|c|c|c|c|c|c|}
\hline Year & Z. noltii beds & $\begin{array}{l}\text { Intermediate area } \\
\text { (muddy) }\end{array}$ & $\begin{array}{l}\text { Eutrophic area (sand-- } \\
\text { muddy) }\end{array}$ & South arm's intertidal area & \\
\hline 1993 & $\begin{array}{l}P: 148.0 \\
(\bar{B}: 75.1)\end{array}$ & $P: 30.7(\bar{B}: 20.1)$ & $P: 89.3(\bar{B}: 31.4)$ & $\begin{array}{l}1.4 \% \text { Z. noltii, } 84.9 \% \text { muddy, } 13.7 \% \text { sand-muddy; } \\
\text { Macroalgal bloom }\end{array}$ & $\begin{array}{l}P: 40.4 \\
(\bar{B}: 26.9)\end{array}$ \\
\hline 1994 & $\begin{array}{l}P: 222.9 \\
(\bar{B}: 84.6)\end{array}$ & $P: 60.3(\bar{B}: 23.4)$ & $P: 45.8(\bar{B}: 15.8)$ & $1.1 \%$ Z. noltii, $85.2 \%$ muddy, $13.7 \%$ sand-muddy & $\begin{array}{l}P: 60.1 \\
(\bar{B}: 23.3)\end{array}$ \\
\hline 1995 & $\begin{array}{l}P: 137.9 \\
(\bar{B}: 105.8)\end{array}$ & $P: 48.8(\bar{B}: 30.1)$ & $P: 32.8(\bar{B}: 19.7)$ & $\begin{array}{l}0.72 \% \text { Z. noltii, } 85.6 \% \text { muddy, } 13.7 \% \text { sand-muddy; } \\
\text { Small macroalgal bloom }\end{array}$ & $\begin{array}{l}P: 47.3 \\
(\bar{B}: 29.5)\end{array}$ \\
\hline 1996 & - & - & $P: 30.3(\bar{B}: 25.8)$ & - & - \\
\hline 1997 & - & - & - & $0.013 \%$ Z. noltii, $86.3 \%$ muddy, $13.7 \%$ sand-muddy & - \\
\hline 1998 & \multicolumn{5}{|c|}{ Mitigation measures } \\
\hline 1999 & $\begin{array}{l}P: 45.9 \\
(\bar{B}: 34.9)\end{array}$ & $P: 27.7(\bar{B}: 20.9)$ & $P: 57.0(\bar{B}: 45.0)$ & $0.019 \%$ Z. noltii, $86.0 \%$ muddy, $13.7 \%$ sand-muddy & $\begin{array}{l}P: 28.1 \\
(\bar{B}: 24.2)\end{array}$ \\
\hline 2000 & $\begin{array}{l}P: 121.3 \\
(\bar{B}: 60.1)\end{array}$ & $P: 35.5(\bar{B}: 37.5)$ & $P: 60.6(\bar{B}: 62.3)$ & $0.57 \%$ Z. noltii; $85.7 \%$ muddy; $13.7 \%$ sand-muddy & $\begin{array}{l}P: 39.5 \\
(\bar{B}: 41.0)\end{array}$ \\
\hline 2001 & $\begin{array}{l}P: 88.4 \\
(\bar{B}: 54.4)\end{array}$ & $P: 34.4(\bar{B}: 29.2)$ & $P: 51.7(\bar{B}: 37.8)$ & $1.0 \%$ Z. noltii, $85.3 \%$ muddy, $13.7 \%$ sand-muddy & $\begin{array}{l}P: 37.3 \\
(\bar{B}: 30.7)\end{array}$ \\
\hline 2002 & $\begin{array}{l}P: 199.5 \\
(\bar{B}: 94.8)\end{array}$ & $P: 55.9(\bar{B}: 48.4)$ & $P: 58.2(\bar{B}: 35.0)$ & $1.4 \%$ Z. noltii, $84.9 \%$ muddy, $13.7 \%$ sand-muddy & $\begin{array}{l}P: 58.3 \\
(\bar{B}: 47.2)\end{array}$ \\
\hline
\end{tabular}

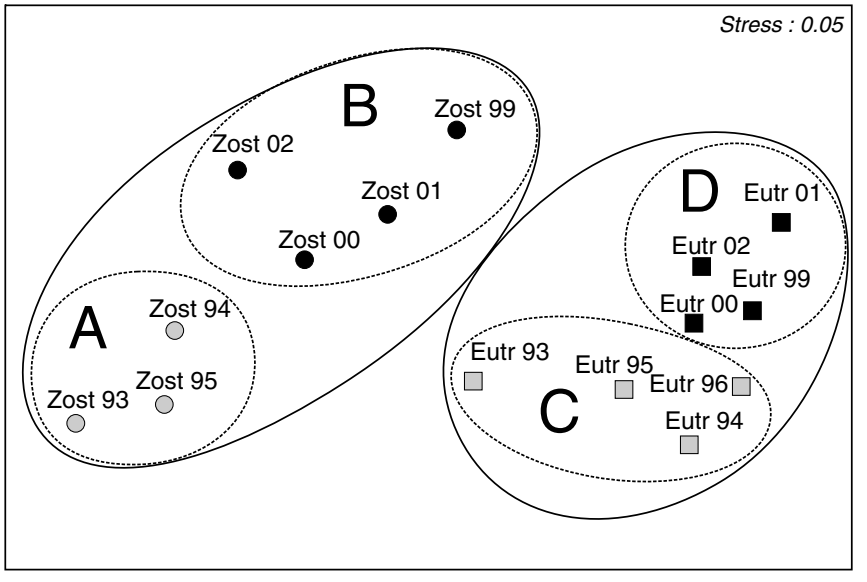

Fig. 4. Two-dimensional non-metric MDS ordination plot of macrobenthic community production for the $Z$. noltii bed (ZOST, circles) and the eutrophic area (EUTR, squares). Grey symbols, before mitigation measures; black symbols, after mitigation measures; A, B, C, D, spatial aggregation of the different groups, defined in the MDS. production, which increased again in the following year (Table 3).

Cyathura carinata production was also higher in the eutrophic area, but after the mitigation measures it increased in the $Z$. noltii beds, although never reaching the production values of the eutrophic area (Table 3 ). The $P / \bar{B}$ ratios were in general higher in the $Z$. noltii beds.

Production by $H$. diversicolor started slightly greater in the eutrophic area. After mitigation measures, it increased for both areas, but remained higher in the $Z$. noltii beds, especially over the last 2 years of the study, 2001 and 2002 (Table 3).

\section{Discussion}

Previous studies on the Mondego estuary have shown that the system is highly productive (Dolbeth et al., 2003), in line with other systems elsewhere (see for example, Sprung, 1994; Heck et al., 1995). The present study

Table 2

MDS formed groups for the Z. noltii and eutrophic areas' production, with indication each group similarities (\%) and the most representative species (\%) contributing for the similarity within the group, determined with SIMPER analysis

\begin{tabular}{lllll}
\hline Group & A & B & C & D \\
\hline Site and year & Z. noltii bed 93-95 & Z. noltii bed 99-02 & Eutrophic area 93-95 & Eutrophic area 96, 99-02 \\
Group mean similarity (\%) & 78.42 & 73.88 & 75.54 & 83.13 \\
Main species (after each & H. ulvae -44.7 & H. ulvae -39.9 & C. carinata -34.1 & S. plana -37.6 \\
species the \% of & C. edule -7.6 & S. plana -19.3 & H. calvae -22.4 & H. ulvae -10.4 \\
contribution for the & S. plana -7.1 & H. diversicolor -11.8 & S. plana -21.1 & H. diversicolor -10.1 \\
similarity within the & L. littorea -5.0 & C. carinata -7.0 & H. diversicolor -8.2 & \\
group) & H. filiformis -4.4 & C. maenas -4.7 & & \\
& C. maenas -3.9 & & & \\
& M. palmata -3.4 & & & \\
& C. carinata -3.2 & & & \\
& A. valida -2.1 & &
\end{tabular}


Table 3

Annual production $\left(P: \mathrm{g} \mathrm{AFDW} \mathrm{m}^{-2} \mathrm{yr}^{-1}\right)$, mean biomass $\left(\bar{B}: \mathrm{g}\right.$ AFDW m$\left.{ }^{-2}\right)$ and $P / \bar{B}$ ratios $\left(P / \bar{B}: \mathrm{yr}^{-1}\right)$ estimates for the main species for the $Z$. noltii and eutrophic areas

\begin{tabular}{|c|c|c|c|c|c|c|c|c|c|c|c|c|}
\hline \multirow[t]{2}{*}{ Year } & \multicolumn{3}{|c|}{ H. ulvae } & \multicolumn{3}{|c|}{ S. plana } & \multicolumn{3}{|c|}{ C. carinata } & \multicolumn{3}{|c|}{ H. diversicolor } \\
\hline & $P$ & $\bar{B}$ & $P / \bar{B}$ & $P$ & $\bar{B}$ & $P / \bar{B}$ & $P$ & $\bar{B}$ & $P / \bar{B}$ & $P$ & $\bar{B}$ & $P / \bar{B}$ \\
\hline \multicolumn{13}{|c|}{ Z. noltii bed } \\
\hline 1993 & 122.6 & 59.2 & 2.1 & 3.0 & 3.4 & 0.9 & 0.4 & 0.1 & 4.6 & 0.2 & 0.1 & 2.0 \\
\hline 1994 & 204.3 & 74.1 & 2.8 & 2.9 & 1.6 & 1.8 & 3.2 & 1.1 & 2.9 & 0.9 & 0.7 & 1.3 \\
\hline 1995 & 110.5 & 82.1 & 1.3 & 3.5 & 2.7 & 1.3 & 3.8 & 1.3 & 3.0 & 0.5 & 0.4 & 1.3 \\
\hline 1999 & 26.8 & 11.3 & 2.4 & 10.8 & 15.8 & 0.7 & 0.9 & 0.4 & 2.4 & 3.4 & 3.1 & 1.1 \\
\hline 2000 & 95.4 & 32.0 & 3.0 & 13.9 & 17.0 & 0.8 & 3.4 & 1.7 & 2.0 & 2.9 & 2.1 & 1.4 \\
\hline 2001 & 62.0 & 30.3 & 2.0 & 9.6 & 14.9 & 0.6 & 3.6 & 1.7 & 2.2 & 10.8 & 6.5 & 1.7 \\
\hline 2002 & 167.1 & 65.7 & 2.5 & 12.7 & 16.6 & 0.8 & 1.4 & 0.6 & 2.2 & 10.3 & 7.4 & 1.4 \\
\hline \multicolumn{13}{|c|}{ Eutrophic area } \\
\hline 1993 & 45.3 & 9.4 & 4.8 & 18.4 & 11.6 & 1.6 & 19.8 & 6.9 & 2.9 & 1.0 & 0.5 & 2.0 \\
\hline 1994 & 10.9 & 2.4 & 4.5 & 6.7 & 4.2 & 1.6 & 29.2 & 8.6 & 3.4 & 0.7 & 0.4 & 1.8 \\
\hline 1995 & 8.6 & 3.6 & 2.4 & 6.6 & 6.3 & 1.0 & 14.8 & 8.8 & 1.7 & 1.5 & 1.0 & 1.5 \\
\hline 1996 & 3.1 & 1.0 & 3.1 & 8.7 & 14.4 & 0.6 & 16.4 & 8.5 & 1.9 & 1.6 & 1.4 & 1.1 \\
\hline 1999 & 3.2 & 1.1 & 2.9 & 34.1 & 33.6 & 1.0 & 17.5 & 11.2 & 1.6 & 1.1 & 0.8 & 1.4 \\
\hline 2000 & 8.3 & 2.0 & 4.1 & 34.8 & 36.8 & 0.9 & 14.8 & 9.9 & 1.5 & 1.9 & 1.0 & 1.9 \\
\hline 2001 & 1.3 & 0.5 & 2.7 & 24.6 & 25.5 & 1.0 & 15.7 & 7.9 & 2.0 & 5.6 & 2.9 & 1.9 \\
\hline 2002 & 4.5 & 1.2 & 3.6 & 24.7 & 20.9 & 1.2 & 21.6 & 7.9 & 2.7 & 5.8 & 2.9 & 2.0 \\
\hline
\end{tabular}

confirms the high estuarine production of the Mondego estuary and demonstrates that seagrass beds are more productive and support higher species richness than bare muddy/sandy areas, as seen also by Sprung (1994) and Heck et al. (1995). Seagrass beds provide essential processes and services, such as nutrient cycling, detritial production and export, sediment stabilization and optimal habitat for growth, survival and reproduction for a variety of fish and invertebrate species (Heck et al., 2003; Cunha et al., 2005; Polte et al., 2005), which have been pointed out as the major reasons for the importance of the habitat. Yet, seagrass beds are in decline around the world (Short and Neckles, 1999; De Jonge and de Jong, 2002; Charpentier et al., 2005; Munkes, 2005). As shown here for the Mondego, such decline will lead to a reduction of both species richness and production of the whole estuary. The need for active restoration programs becomes urgently required worldwide (De Jonge and de Jong, 2002; Cardoso et al., 2004b; Pardal et al., 2004; Lillebø et al., 2005; Martins et al., 2005; Munkes, 2005), and especially for the Mondego estuary, since there is evidence that the $Z$. noltii beds and eutrophic area are alternate stable states in the system between which it is difficult to shift without major intervention (Cardoso et al., 2004a). Eutrophication symptoms and impacts on the biological communities were pointed out as major reasons for the decline of the $Z$. noltii beds and for the restructure of living biota (Dolbeth et al., 2003; Marques et al., 2003; Pardal et al., 2004; Cardoso et al., 2005; Verdelhos et al., 2005). For the Mondego, a shift from seagrass beds to areas covered by green macroalgae (eutrophic areas) seemed to occur. Natural disturbances appeared not to be the main factor triggering the observed changes, as seen in Cunha et al. (2005), with exception for 2000/01, when the big flood occurred. This shift clearly represents a loss of the ecological integrity of the whole estuary
(Marques et al., 2003). Within this 10-year period, the Mondego has experienced several extremes of biological, chemical and physical stress (Cardoso et al., 2005; Lillebø et al., 2005). The macroalgal bloom observed in 1993 in the eutrophic area stimulated a pulse of production. Macroalgae may function as temporary habitats for macrofauna (Salovius et al., 2005), but their benefits are quite short-lived, as the long-term effects necessarily imply a loss of the estuarine production (Dolbeth et al., 2003). Additionally, the extreme salinity fluctuations, induced by floods, seemed also to have an impact on the plant and faunal communities. Estuaries are defined by salinity change over tidal cycles, but floods (of varying intensity, frequency and duration) can alter salinity regimes dramatically to the detriment of the benthic communities (Ritter et al., 2005). With future climate change, more extreme fluctuations in salinity are expected, which in turn will affect both plant (Short and Neckles (1999) review for seagrass) and faunal communities (Lawrence and Soame, 2004). Ecosystems such as the Mondego estuary will have to deal with the effect of multiple stressors, which may act synergistically to considerable lower the resilience and resistance of the populations to disturbance (Adams, 2005; Cardoso et al., 2005).

There is evidence that the implementation of the mitigation measures in the Mondego estuary at the end of 1998 have been effective, regarding the water and environment quality improvement in the south arm. Nutrient loading was significantly reduced and no further macroalgal blooms were recorded (Cardoso et al., 2005; Lillebø et al., 2005). In addition, $Z$. noltii is gradually recovering, both in biomass and extent, and now is even starting to re-colonise the intermediate area (personal observation). With respect to the macrobenthic community recovery, all areas showed an increase in mean biomass, production 
and species richness from the low values achieved at the beginning of the post-mitigation period in 1999. This translated into an increase of the mean estuarine biomass and production for the whole south arm of the estuary. Nevertheless, the numbers of species have not yet attained former levels. The initial recovery response of the macroinvertebrate community appears to be with an increase in total biomass or energy, to which the opportunistic species mainly contributed, but not in complexity. This was particularly clear for the years following disturbance events, such as the macroalgal bloom followed by a crash in 1993, and the extreme flood in 2000/01. Kennish (2002) provides, for a hypothetical whole estuary, the mean macrobenthos production approaching $50 \mathrm{~g} \mathrm{AFDW} \mathrm{m}^{-2} \mathrm{yr}^{-1}$ and the mean biomass up to $25 \mathrm{~g}_{\text {AFDW m }}{ }^{-2}$. These values corresponds with to the ones estimated for the whole Mondego's south arm, yet following the disturbances in 1994 and 2002, the estuarine production clearly exceeded the $50 \mathrm{~g}$ AFDW $\mathrm{m}^{-2} \mathrm{yr}^{-1}$, and in the post-mitigation period the mean biomass was also exceeded. This seems the system response to the maximization of the available resources, which takes place through a more efficient species composition (Marques et al., 2003). Especially in 1994, the production values are higher, but not the mean biomass values (higher $P / \bar{B}$ ratio of the community), suggesting a higher turnover of the community. The most opportunistic species (r-strategists), such as $H$. ulvae, seemed to prevail with the major production after disturbance periods. Hydrobia ulvae was clearly the dominant producer in the $Z$. noltii beds, with lower $P / \bar{B}$ ratios in this area, as it presents structured populations with all age classes, while in the eutrophic area the population is dominated by juveniles (unstable population with higher turnover rates) (Cardoso et al., 2005). This species alone, contributed to the major part of all Z. noltii beds production (more than 80\%) before the mitigation measures and then again in 2002 . However, in the latest years of the study, there is some evidence of succession from r-strategists towards K-strategists species. Scrobicularia plana, typically a slow growing species, increased considerably in the estuary after the mitigation measures, especially in the eutrophic area, probably responsible by the increase of the estuarine mean biomass in the estuary. $P / \bar{B}$ ratios were lower in the post-mitigation period, suggesting higher stability of the population, and agreeing with the typical values of about 1.0 for longerliving molluscs (McLusky, 1989). Consistent with the successional paradigm, $H$. diversicolor, which is also a longer-lived and larger-bodied species, increased its production mainly at the end of study in 2001 and 2002. The increase in these species has contributed to the general increase in the mean estuarine biomass during the post-mitigation period. Cyathura carinata maintained its dominance in the eutrophic area, where it is tolerant to macroalgal blooms and floods (Ferreira et al., 2007). Also, there is the possibility of higher parasite pressure in the $Z$. noltii area, inhibiting $C$. carinata reproduction and making the population more erratic, which might also explain the lower production in the area and the higher $P / \bar{B}$ ratios registered, especially in the pre-mitigation period (Ferreira et al., 2007).

When interpreting the present results the prior disturbance history of a site has also to be taken into account. Thus, after the flood of 1993/94, production and species richness appeared to recover quicker when compared to after the flood in 2000/01. In fact, by the time of the extreme flood in 2000/01, the species richness was much lower and this may have compromised the recovery process, consistent with current thinking on system resilience provided by biodiversity (Loreau et al., 2002; Marques et al., 2003; Raffaelli et al., 2003). If biodiversity is severely reduced by one stressor, then the effects of subsequent ones may be much greater than imagined. When considered alone, both $Z$. noltii beds and the eutrophic area responded to disturbance in similar ways, but at different rates. Thus, the $Z$. noltii beds were able to reduce production during a disturbance and almost double it afterwards, while the eutrophic area production only showed a slow tendency to increase production. $Z$. noltii beds are considered to represent the original more pristine conditions of the estuary (Marques et al., 2003), whereas the eutrophic area represents the loss of ecological integrity. Actually, in the beginning of the 1980s, the $Z$. noltii beds covered a large fraction of the intertidal area, extending to the upstream section of the south arm, where is located the eutrophic area (Marques et al., 2003). At the present time the $Z$. noltii beds are recovering but the eutrophic area restoration is still far away from a habitat similar to the $Z$. noltii beds. Quite recently, some very small patches of $Z$. noltii are appearing in the eutrophic area (personal observation), but the plant recovery is not fully taking place. As a simple bare sandy/ muddy habitat, the eutrophic area appears less variable over time. Potentially this area may be reaching a new steady state community for bare sand/mud, which is consistent with the increase of the K-strategists species (e.g. S. plana) in this area.

\section{Acknowledgements}

This work was supported by the F.C.T. (Portuguese Foundation for Science and Technology) through a Ph.D. grant attributed to M. Dolbeth (SFRH/BD/14112/2003). The authors are indebted to all colleagues from IMARCoimbra that participated in field and laboratory work.

\section{References}

Adams, S.M., 2005. Assessing cause and effect of multiple stressors on marine systems. Marine Pollution Bulletin 51, 649-657.

Beukema, J.J., Dekker, R., 2005. Decline of recruitment success in cockles and other bivalves in the Wadden Sea: possible role of climate change, predation on postlarvae and fisheries. Marine Ecology Progress Series 287, 149-167.

Brey, T., 2001. Population dynamics in benthic invertebrates. A virtual handbook. Version 01.2. http://www.awi-bremerhaven.de/Benthic/ Ecosystem/FoodWeb/Handbook/main.html Alfred Wegener Institute for Polar and Marine Research, Germany. 
Cardoso, P.G., Pardal, M.A., Lillebø, A.I., Ferreira, S.M., Raffaelli, D., Marques, J.C., 2004a. Dynamic changes in seagrass assemblages under eutrophication and implications for recovery. Journal Experimental Marine Biology and Ecology 302, 233-248.

Cardoso, P.G., Pardal, M.A., Raffaelli, D., Baeta, A., Marques, J.C., 2004b. Macroinvertebrate response to different species of macroalgal mats and the role of disturbance history. Journal Experimental Marine Biology and Ecology 308, 207-220.

Cardoso, P.G., Brandão, A., Pardal, M.A., Raffaelli, D., Marques, J.C., 2005. Resilience of Hydrobia ulvae populations to anthropogenic and natural disturbances. Marine Ecology Progress Series 289, 191199.

Charpentier, A., Grillas, P., Lescuyer, F., Coulet, E., Auby, I., 2005. Spatio-temporal dynamics of a Zostera noltii dominated community over a period of fluctuating salinity in a shallow lagoon, Southern France. Estuarine Coastal and Shelf Science 64, 307-315.

Clarke, K.R., Warwick, R.M., 2001. Change in Marine Communities. An Approach to Statistical Analysis and Interpretation, second ed. Primer-E, Plymouth.

Cunha, A.H., Santos, R.P., Gaspar, A.P., Bairros, M.F., 2005. Seagrass landscape-scale changes in response to disturbance created by the dynamics of barrier-islands: a case from Ria Formosa (Southern Portugal). Estuarine, Coastal and Shelf Science 64, 636-644.

Cusson, M., Bourget, E., 2005. Global patterns of macroinvertebrate production in marine benthic habitats. Marine Ecology Progress Series 297, 1-14.

De Jonge, V.N., de Jong, D.J., 2002. Ecological restoration in coastal areas in the Netherlands: concepts, dilemmas and some examples. Hydrobiologia 478, 7-28.

Dexter, D.M., 1983. Community structure of intertidal sandy beaches in new South, Australia. In: McLachlan, A., Erasmus, T. (Eds.), Sandy Beaches as Ecosystems. W. Junk Publishers, The Hague, pp. 461472.

Dolbeth, M., Pardal, M.A., Lillebø, A.I., Azeiteiro, U.M., Marques, J.C., 2003. Short and long-term effects of eutrophication on the secondary production of an intertidal macrobenthic community. Marine Biology $143,1229-1238$.

Dolbeth, M., Lillebø, A.I., Cardoso, P.G., Ferreira, S.M., Pardal, M.A., 2005. Annual production of estuarine fauna in different environmental conditions: an evaluation of the estimation methods. Journal Experimental Marine Biology and Ecology 326, 115-127.

Ferreira, S.M., Pardal, M.A., Lillebø, A.I., Cardoso, P.G., Marques, J.C., 2004. Population dynamics of Cyathura carinata (Isopoda) in a eutrophic temperate estuary. Estuarine Coastal and Shelf Science 61, 669-677.

Ferreira, S.M., Brandão, A., Baeta, A., Neto, J.M., Lillebø, A.I., Marques, J.C., Jensen, K.T., Pardal, M.A., 2007. Effects of restoration management on the estuarine isopod Cyathura carinata: mediation by trematodes and habitat change. Marine Biology, in press. doi:10.1007/ s00227-006-0455-5.

Heck, K.L., Able, K.W., Roman, C.T., Fahay, M.P., 1995. Composition, abundance, biomass, and production of macrofauna in a New England Estuary - comparisons among eelgrass beds and other nursery habitats. Estuaries 18 (2), 379-389.

Heck, K.L., Hays, G., Orth, R.J., 2003. Critical evaluation of the nursery role hypothesis for seagrass meadows. Marine Ecology Progress Series 253, 123-136.

Kennish, M.J., 2002. Environmental threats and environmental futures of estuaries. Environmental Conservation 29 (1), 78-107.

Lawrence, A.J., Soame, J.M., 2004. The effects of climate change on the reproduction of coastal invertebrates. Environmental Conservation 146 (Suppl. 1), 29-39.
Lillebø, A.I., Neto, J.M., Martins, I., Verdelhos, T., Leston, S., Cardoso, P.G., Ferreira, S.M., Marques, J.C., Pardal, M.A., 2005. Management of a shallow temperate estuary to control eutrophication: the effect of hydrodynamics on the system's nutrient loading. Estuarine Coastal and Shelf Science 65, 697-707.

Loreau, M., Dowining, A., Emmerson, M., Gonzalez, A., Hughes, J., Inchausti, P., Joshi, J., Norberg, J., Sala, O., 2002. A new look at the relationship between diversity and stability. In: Loreau, M., Naeem, S., Inchausti, P. (Eds.), Biodiversity and Ecosystem Functioning. Oxford University Press, Oxford, pp. 79-91.

Marques, J.C., Nielsen, S.N., Pardal, M.A., Jørgensen, S.E., 2003. Impact of eutrophication and river management within a framework of ecosystem theories. Ecological Modelling 166, 147-168.

Martins, I., Neto, J.M., Fontes, M.G., Marques, J.C., Pardal, M.A., 2005. Seasonal variation in short-term survival of Zostera noltii transplants in a declining meadow in Portugal. Aquatic Botany 82, 132-142.

McLusky, D.S., 1989. The Estuarine Ecosystem, second ed. Chapman and Hall, New York, 215pp.

Munkes, B., 2005. Eutrophication, phase shift, the delay and the potential return in the Greifswalder Bodden, Baltic Sea. Aquatic Science 67, 372-381.

Paerl, H.W., 2006. Assessing and managing nutrient-enhanced eutrophication in estuarine and coastal waters: interactive effects of human and climatic perturbations. Ecological Engineering 26, 40-54.

Pardal, M.A., Marques, J.C., Metelo, I., Lillebø, A., Flindt, M.R., 2000. Impact of eutrophication on the life cycle, population dynamics and production of Amphitoe valida (Amphipoda) along an estuarine spatial gradient (Mondego Estuary, Portugal). Marine Ecology Progress Series 196, 207-219.

Pardal, M.A., Cardoso, P.G., Sousa, J.P., Marques, J.C., Raffaelli, D., 2004. Assessing environmental quality: a novel approach. Marine Ecology Progress Series 267, 1-8.

Pihl, L., Magnusson, G., Isaksson, I., Wallentinus, I., 1996. Distribution and growth dynamics of ephemeral macroalgae in shallow bays on the Swedish west coast. Journal of Sea Research 35 (1-3), 169-180.

Polte, P., Schanz, A., Asmus, H., 2005. The contribution of seagrass beds (Zostera noltii) to the function of tidal flats as a juvenile habitat for dominant, mobile epibenthos in the Wadden Sea. Marine Biology 147, 813-822.

Powers, S.P., Peterson, C.H., Christian, R.R., Sullivan, E., Powers, M.J., Bishop, M.J., Buzzelli, C.P., 2005. Effects of eutrophication on bottom habitat and prey resources of demersal fishes. Marine Ecology Progress Series 302, 233-243.

Raffaelli, D., Emmerson, M., Solan, M., Biles, C., Paterson, D., 2003. Biodiversity and ecosystem processes in shallow coastal waters: an experimental approach. Journal of Sea Research 49, 133-141.

Ritter, C., Montagna, P.A., Applebaum, S., 2005. Short-term succession dynamics of macrobenthos in a salinity-stressed estuary. Journal Experimental Marine Biology and Ecology 323, 57-69.

Salovius, S., Nyqvist, M., Bonsdorff, E., 2005. Life in the fast lane: macrobenthos use temporary drifting algal habitats. Journal of Sea Research 53, 169-180.

Short, F.T., Neckles, H.A., 1999. The effects of global climate change on seagrasses. Aquatic Botany 63, 169-196.

Simas, T., Nunes, J.P., Ferreira, J.G., 2001. Effects of global climate change on coastal salt marshes. Ecological Modelling 139, 1-15.

Sprung, M., 1994. Macrobenthic secondary production en the Intertidal Zone of Ria Formosa - a lagoon in Southern Portugal. Estuarine Coastal and Shelf Science 38, 539-558.

Verdelhos, T., Neto, J.M., Marques, J.C., Pardal, M.A., 2005. The effect of eutrophication and coastal management on the bivalve Scrobicularia plana. Estuarine Coastal and Shelf Science 63, 261-268. 